\title{
Features Of Photosynthesis And Water Regime Of Quercus Pubescens Willd. Under The Conditions Of Autumn Drought Of The Southern Coast Of The Crimea
}

\author{
O.A. Ilnitsky*,$Y . V$. Plugatar, A.V. Pashtetsky, and A.T. Gil
}

The Nikitsky Botanical Gardens - National Scientific Center of the RAS, 52 Nikitsky spusk street, Nikita village, Yalta 298648, Russia

\begin{abstract}
The objective of the research is to determine the optimal zones and thresholds of soil moisture, temperature, illumination, limiting photosynthesis and transpiration of Quércus pubéscens Willd. and allowing the introduction of the species to other regions. The dependences of the net photosynthesis rate $\left(\mathrm{P}_{\mathrm{n}}\right)$ and the transpiration rate $(\mathrm{E})$ on stomatal conductivity $\left(\mathrm{g}_{\mathrm{s}}\right)$, leaf temperature $\left(\mathrm{T}_{\mathrm{l}}\right)$, and soil moisture $\left(\mathrm{W}_{\mathrm{s}}\right)$ are shown. The ratio of the processes of photosynthesis and respiration, under the influence of soil drought, allowed us to define their optimal values: $\mathrm{W}_{\mathrm{s}}=$ $26-28 \%, \mathrm{P}_{\mathrm{n}}=16-18 \mu \mathrm{mol} / \mathrm{m}^{2} \mathrm{c}, \mathrm{Rt}=2-4 \mu \mathrm{mol} / \mathrm{m}^{2} \mathrm{c}$. The relationship between the net photosynthesis rate, total respiration, and leaf temperature allowed us to determine the temperature maximum of net photosynthesis (the thermal compensation point): $\mathrm{P}_{\mathrm{n}}=\mathrm{R}_{\mathrm{t}}=2.0 \mu \mathrm{mol} / \mathrm{m}^{2} \mathrm{c}$ at $\mathrm{T}_{1}=37^{\circ} \mathrm{C}$. It was found that in the absence of soil drought, the proportion of respiratory costs $\left(\mathrm{R}_{\mathrm{t}} / \mathrm{P}_{\mathrm{g}}\right)$ from true photosynthesis is $20-23 \%$, and with soil moisture of $8-10 \%$ increases to $55-58 \%$.
\end{abstract}

\section{Introduction}

The features of the climate of the Southern Coast of the Crimea (SCC), which is a region of dry subtropics, allow us to preserve natural vegetation, establish new and reconstruct existing green spaces that are in the conditions of a microclimate formed by the environment [1].

When selecting such plant species, it is necessary to study various processes of vital activity in the conditions of their growth. Quércus pubéscens Willd. is one of the main forest-forming species on the coasts of the Black Sea, the Mediterranean Sea [2] and other regions [3].

In the Mediterranean basin, where drought and air pollution, such as tropospheric ozone $\left(\mathrm{O}_{3}\right)$, are the main limiting factors of productivity, studies were conducted on seedlings of three oak species, including Quércus pubéscens Willd. [4].

Favorable and limiting environmental factors for Quercus pubescens Willd. in the

\footnotetext{
${ }^{*}$ Corresponding author: ilnitsky.oleg@mail.ru
} 
Transylvanian basin were evaluated by geographic information system (GIS) methods [5]. A model of spatial analysis has been developed to determine the territories favorable for the growth of pubescent oaks. The model has a high degree of confidence as a comparative direct monitoring for the analysis of planned forestry (validation coefficient 93\%).

The impact of seasonal environmental changes (primarily drought) on the photosynthetic and morphological characteristics of leaves, including Quércus pubéscens Willd., is shown in the work [6]. Plant resistance to drought and heat waves is determined by their frequency and duration, which are projected to become much more severe under current climate change scenarios, especially in the Mediterranean region [7].

The physiological and biochemical reactions of Quercus pubescens Willd. on high air temperature and drought on acidic and calcareous soils were studied in the subMediterranean region [8].

Increasing atmospheric carbon dioxide concentrations has important implications for the future growth and productivity of natural and managed ecosystems, and is of particular interest for identifying carbon sinks useful for maintaining the efficiency of carboxylation in plant responses to elevated $\mathrm{CO}_{2}$ levels by eliminating excess reduced carbon [9].

On seedlings and trees of Quercus pubescens Willd. the dependence of pure photosynthesis, leaf conductivity, transpiration, isoprene emission, and chlorophyll fluorescence on the lack of air humidity and $\mathrm{CO}_{2}$ concentration was studied (central Italy).

Seasonal responses of the water regime and photochemical efficiency of photosystem II to summer water deficit in one year old seedlings of Quercus pubescens, Quercus ithaburensis and Quercus frainetto were studied in the field in Greece [10].

The influence of climatic factors on the daily fluctuations of photosynthesis was studied in Quercus pubescens Willd., which grows in the Swiss Alps during the period when record heat was observed in Central Europe [11]. Severe drought and heat caused a sharp decrease in the daily rate of assimilation $\left(\mathrm{P}_{\mathrm{n}}\right)$.

Quercus pubescens Willd. is a winter deciduous species, and summer drought and high temperatures limit the intensity of photosynthesis. This restriction can be expected to increase if the climate continues to warm. In the Mediterranean basin, precipitation is expected to decrease by more than $25-30 \%$ by the end of the $21^{\text {st }}$ century, probably accompanied by an increase of $4-5^{\circ} \mathrm{C}$ in average annual temperatures [7].

\section{Materials and Methods}

The pubescent oak (Quercus pubéscens Willd.) is a species of white oak (genus Quercus sect. Quercus), native to southern Europe and southwest Asia, from northern Spain (Pyrenees) east to the Crimea and the Caucasus [2]. It is also found in France and parts of Central Europe. Pubescent oak usually grows in dry, lime-rich soils. Often on the coastal and southern slopes, it forms communities with rock oak and eastern hornbeam, less often with junipers. It grows on the areas up to $400 \mathrm{~m}$ above sea level. It forms low-growing oak crook-stem forests - maquises, extremely light-loving and drought-resistant, quite frostresistant and moderately salt-resistant. It is a sub-Mediterranean species, growing from the coastline to the depths of the continent. Deciduous tree $12-18 \mathrm{~m}$ high. The crown is broad, spreading-rounded, dense. The shoots are densely felt-pubescent, brown-olive, then gray. Leaves $5-10 \mathrm{~cm}$ long and $2-5 \mathrm{~cm}$ wide, obovate or elliptical, with a rounded tip, with a rounded or slightly heart-shaped base. Petioles $6-2 \mathrm{~cm}$ long, acorns $5-2 \mathrm{~cm}$. A large polymorphism in the pubescent oak is manifested in size, shape, leaf lobing, leaf pubescence, etc. The number of chromosomes is $2 \mathrm{n}=24$. Its seedlings are used as rootstocks for other oak species, less xerophytic and more thermophilic.

In the experiment in September - October 2019 - 2020 there were four-year-old seedlings of Quércus pubéscens Willd., grown from cuttings in vegetative vessels. 
The PTM-48A photosynthesis monitor and PM-11z phytomonitor were used for continuous automatic registration of intact leaf gas exchange, plant growth, and water regime [12]. The PTM-48A photosynthesis monitoring system is equipped with four leaf cameras connected to a monitor. The natural concentration of $\mathrm{CO}_{2}$ in the air was approximately $0.04 \%$. To characterize various processes of plant life, the following parameters were used: values of net photosynthesis $-\mathrm{P}_{\mathrm{n}}, \mu \mathrm{mol} / \mathrm{m}^{2} \mathrm{c}$; stomatal conductivity $\mathrm{g}_{\mathrm{s}}, \mathrm{mm} / \mathrm{s}$; transpiration intensity $-\mathrm{E}, \mathrm{mg} / \mathrm{m}^{2} \mathrm{c}$ in the radiation range from 0 to 2000 $\mu \mathrm{mol} / \mathrm{m}^{2} \mathrm{c}$. Photosynthetically active radiation and other environmental parameters: air temperature and humidity were measured by sensors of the PTM-48 weather module connected to the digital input of the RTM-48A system. Photosynthetic radiation sensor TIR-4 (I, $\left.\mu \mathrm{mol} / \mathrm{m}^{2} \mathrm{c}\right)$, needle temperature sensor LT-1P $\left(\mathrm{T}_{\mathrm{xв}},{ }^{\circ} \mathrm{C}\right)$, soil moisture sensor SMS$5 \mathrm{P},\left(\mathrm{W}_{\Pi}\right.$, vol. units. \%), relative sap flow rate in the shoot (Sf, ind. units) - sap flow sensor SF-5P, stem diameter (d, mm.) - sensor SD-10z, apical growth sensor-auxonometer SA-20z $(\mathrm{mm})$. The objective of the research is to study the ecophysiological response of Quércus pubéscens Willd. on the impact of environmental factors that affect the features of the water regime and the intensity of photosynthesis, allowing us to determine the optimal and limiting conditions for their growth.

Statistical data processing was performed using the application computer programs Statistica 10 ("Statsoft Inc.", USA) and Microsoft Excel 2010. Least squares and robust locally weighted regression (Statistica 10) methods were used to model and smooth twodimensional data. All calculations were performed at a given significance level $\mathrm{P} \leq 0.05$.

\section{Results}

The series of experiments conducted in protected ground conditions allowed us to obtain information about a number of ecological and physiological features of the life activity of the studied species and about its responses to the impact of abiotic factors.

Photosynthesis reflects the carbon balance of the leaf in the light and is one of the fundamental processes of plant productivity, responsive to changes in the external environment. The intensity of the factors that ensure the achievement of the optimum of net photosynthesis of plants can be considered as the ecological optimum of the studied genotype [13]. The zones of ecological and physiological optimum of $\mathrm{CO}_{2}$-gas exchange and the intensity of transpiration of Quércus pubéscens Willd. are determined (Fig. 1A, B). At the top of the graphs are the equations of nonlinear regressions of the dependencies between these parameters. The optimum zone is assumed to be the environmental conditions that ensure the intensity of gas exchange or other dependent parameter above $90 \%$ of the maximum [14]. Figure 1A shows the dependence of the net photosynthesis rate of the studied species $\left(\mathrm{P}_{\mathrm{n}}\right)$ on soil moisture and illumination. The optimal values are: $\mathrm{I}=$ $700-900 \mu \mathrm{mol} / \mathrm{m}^{2} \mathrm{~s} ; \mathrm{W}_{\mathrm{s}}=26-28 \% ; \mathrm{P}_{\mathrm{n}}=16-18 \mu \mathrm{mol} / \mathrm{m}^{2} \mathrm{~s}$. Figure $1 \mathrm{~B}$ shows the same dependences for the transpiration rate: $\mathrm{I}=700-900 \mu \mathrm{mol} / \mathrm{m}^{2} \mathrm{~s} ; \mathrm{W}_{\mathrm{s}}=23-28 \% ; \mathrm{E}=55-60$ $\mathrm{mg} / \mathrm{m}^{2} \mathrm{~s}$. 


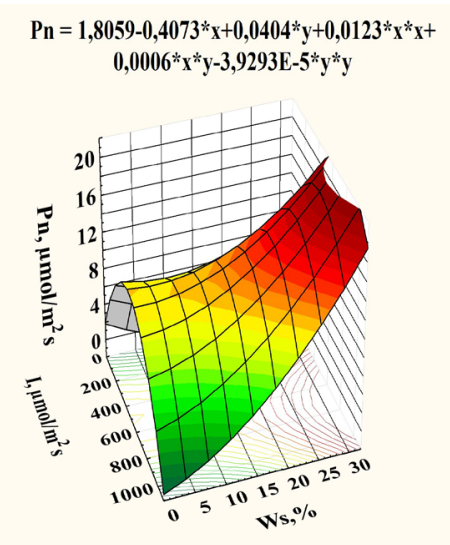

A

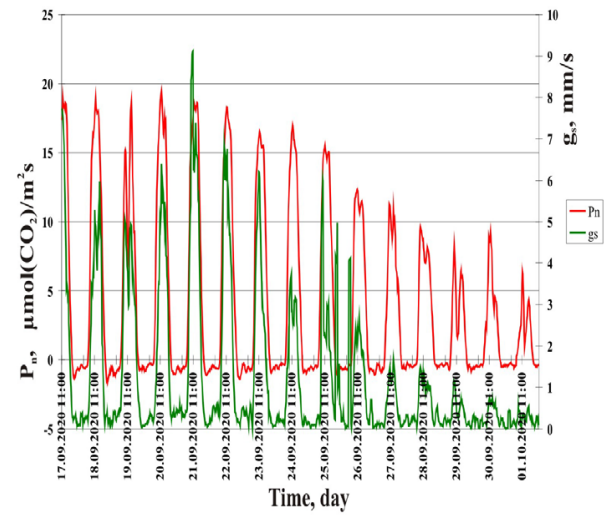

$\mathrm{C}$

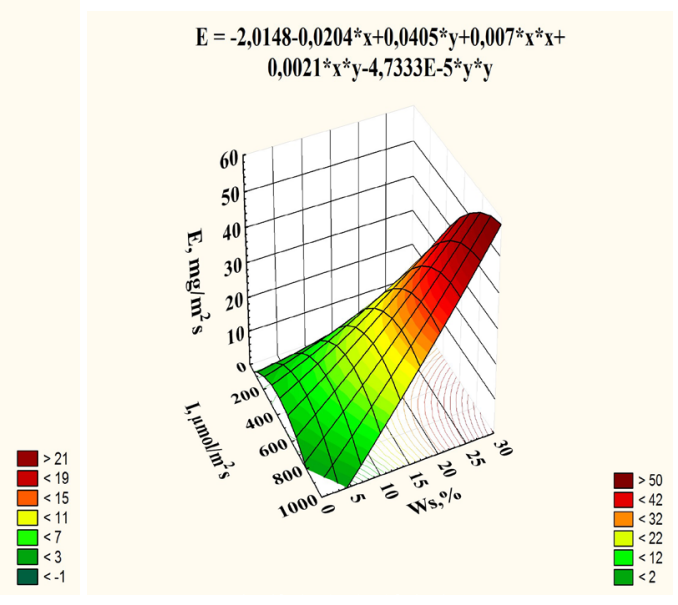

B

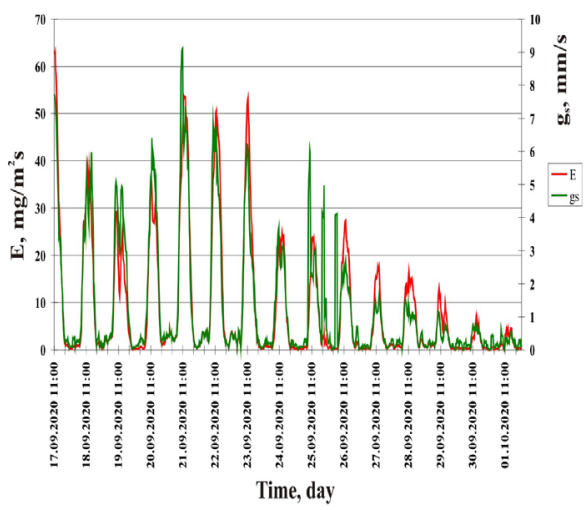

$\mathrm{D}$

Fig.1 Dependence of various processes of Quércus pubéscens Willd.: A - net photosynthesis rate $\left(\mathrm{P}_{\mathrm{n}}\right)$ on soil moisture $(\mathrm{Ws})$ and illumination $(\mathrm{I}) ; \mathrm{B}$ - transpiration rate $(\mathrm{E})$ on soil moisture $\left(\mathrm{W}_{\mathrm{s}}\right)$ and illumination $(\mathrm{I})$; $\mathrm{B}$ - net photosynthesis rate $\left(\mathrm{P}_{\mathrm{n}}\right)$ on stomatal conductivity $\left(\mathrm{g}_{\mathrm{s}}\right)$; D-transpiration rate (E) on stomatal conductivity $\left(\mathrm{g}_{\mathrm{s}}\right)$ [Compiled by the authors].

Environmental conditions can change the diffusion of $\mathrm{CO}_{2}$ molecules and the evaporation of water by changing the stomatal conductivity. This protects plants from overheating and creates the necessary conditions for photosynthesis and transpiration, and ultimately a certain homeostasis of the production process [15].

Figure 1C,D shows the dependence of the net photosynthesis rate $\left(P_{n}\right)$ and the transpiration rate $(\mathrm{E})$ on the stomatal conductivity $\left(\mathrm{g}_{\mathrm{s}}\right)$. In the process of soil drought (September 21, 9:40 - September 30, 9:40) the intensity of net photosynthesis $\left(\mathrm{P}_{\mathrm{n}}\right)$ decreases from 19.0 to $-3.5 \mu \mathrm{mol} / \mathrm{m}^{2} \mathrm{c}$ (Fig. 1C), and the stomatal conductivity ( $\mathrm{g}_{\mathrm{s}}$ ) during this time - from 8 to $0.5 \mathrm{~mm} / \mathrm{s}$.

The transpiration intensity (E) varies from 55 to $1.2 \mathrm{mg} / \mathrm{m}^{2} \mathrm{~s}$ during the same time, and the stomatal conductivity $\left(\mathrm{g}_{\mathrm{s}}\right)-$ from 8 to $0.5 \mathrm{~mm} / \mathrm{s}$ (Fig.1D). Changes in these parameters $\left(\mathrm{P}_{\mathrm{n}}, \mathrm{E}\right)$ occur synchronously and are determined by environmental factors (mainly illumination). 
In the course of the conducted studies, it was found that the stress effect of progressive soil drought with a decrease in soil moisture from 21 to $3.0 \%$ (September $21-30$ ), $\mathrm{P}_{\mathrm{n}}$ changes from 19.5 to $-3.5 \mathrm{mmol} / \mathrm{m}^{2} \mathrm{c}$, and the share of respiratory expenses increased. Figure $2 \mathrm{~A}$ shows the dependence of the net photosynthesis rate of the studied species $\left(\mathrm{P}_{\mathrm{n}}\right)$ and total respiration $\left(\mathrm{R}_{\mathrm{t}}\right)$ on soil moisture. The optimal values are: $\mathrm{W}_{\mathrm{s}}=26-28 \%, \mathrm{P}_{\mathrm{n}}=16$ $-18 \mu \mathrm{mol} / \mathrm{m}^{2} \mathrm{c}$, with such soil moisture, the total respiration $\mathrm{R}_{\mathrm{t}}=2-4 \mu \mathrm{mol} / \mathrm{m}^{2} \mathrm{c}$.

In the process of reducing soil moisture, a change in the ratio of the parameters $P_{n}$ and $P_{t}$ is observed. Since total respiration $\left(R_{t}\right)$ consists of dark respiration $\left(R_{d}\right)$ and photorespiration $\left(\mathrm{R}_{\mathrm{ph}}\right)$, there are changes in the ratio between them (Fig.2B).

After the first watering of the plants (September 21, 11:00) at a soil humidity of $18.2 \%$, these parameters were respectively equal to: $\mathrm{R}_{\mathrm{t}}=1.25 \mu \mathrm{mol} / \mathrm{m}^{2} \mathrm{c}, \mathrm{R}_{\mathrm{d}}=0.8 \mu \mathrm{mol} / \mathrm{m}^{2} \mathrm{c}, \mathrm{R}_{\mathrm{ph}}=$ $0.45 \mu \mathrm{mol} / \mathrm{m}^{2} \mathrm{c}$. In the process of changing the soil moisture to $\mathrm{W}_{\mathrm{s}}=11 \%$, their ratio changed: $\mathrm{R}_{\mathrm{t}}=3 \mu \mathrm{mol} / \mathrm{m}^{2} \mathrm{c}, \mathrm{R}_{\mathrm{d}}=1.75 \mu \mathrm{mol} / \mathrm{m}^{2} \mathrm{c}, \mathrm{R}_{\mathrm{ph}}=0.25 \mu \mathrm{mol} / \mathrm{m}^{2} \mathrm{c}$.

With a decrease in soil moisture to $19.3 \%$ (October 01 ), $19.3 \%$, these ratios were: $\mathrm{R}_{\mathrm{t}}=$ $1.2 \mu \mathrm{mol} / \mathrm{m}^{2} \mathrm{c}, \mathrm{R}_{\mathrm{d}}=1.0 \mu \mathrm{mol} / \mathrm{m}^{2} \mathrm{c}, \mathrm{R}_{\mathrm{ph}}=0.2 \mu \mathrm{mol} / \mathrm{m}^{2} \mathrm{c}$. A further increase in the temperature of the air and the leaf leads to an inhibition of the enzymic activity and a decrease in the intensity of photosynthesis [10]. The dependence of the rate of pure photosynthesis $(\mathrm{Pn})$, total respiration (Rt) on the leaf temperature (Tl) is shown in Fig. $2 \mathrm{C}$. The intersection of the curves of these dependencies (the point of thermal compensation) occurs when their average values are equal $-2.2 \mathrm{mmol} / \mathrm{m}^{2} \mathrm{~s}$ at a leaf temperature of $37^{\circ} \mathrm{C}$ [13]. To estimate the adaptation costs of Quércus pubéscens Willd. under water stress, the intensity of gross photosynthesis (true photosynthesis - $\mathrm{P}_{\mathrm{g}}$ ) and total dark respiration $\mathrm{R}_{\mathrm{t}}$ were used [16,17,18] (Fig.2D).

It was found that at the first stage of the stress effect of progressive soil drought, with soil moisture $\mathrm{W}_{\mathrm{s}}=20-23 \%$, the balance of the physiological processes of photosynthesis and respiration was preserved in the leaves of Quércus pubéscens Willd., and the share of respiratory costs from true photosynthesis was $22-24 \%$. As the combined effects of water and heat stress increased with soil moisture content of $8-10 \%$, the share of respiratory costs from true photosynthesis increased, and before watering it was $55-58 \%$.

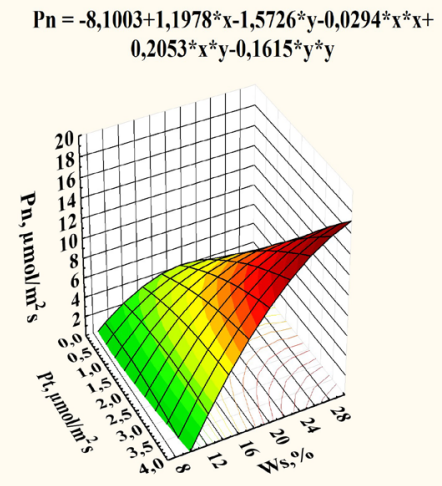

A

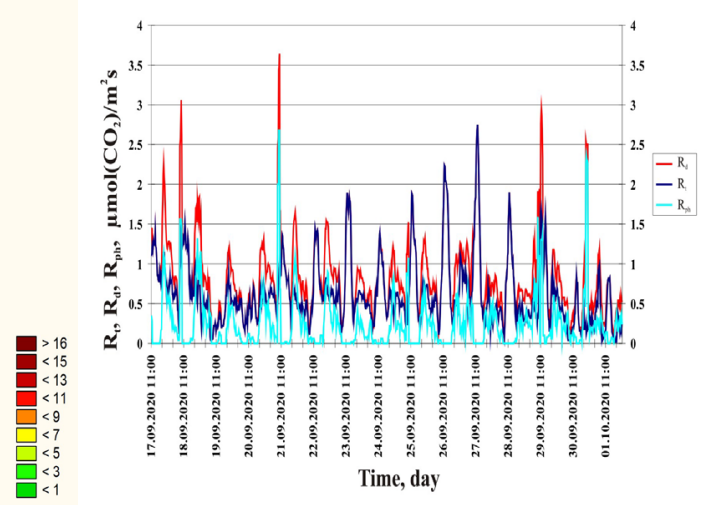

B 


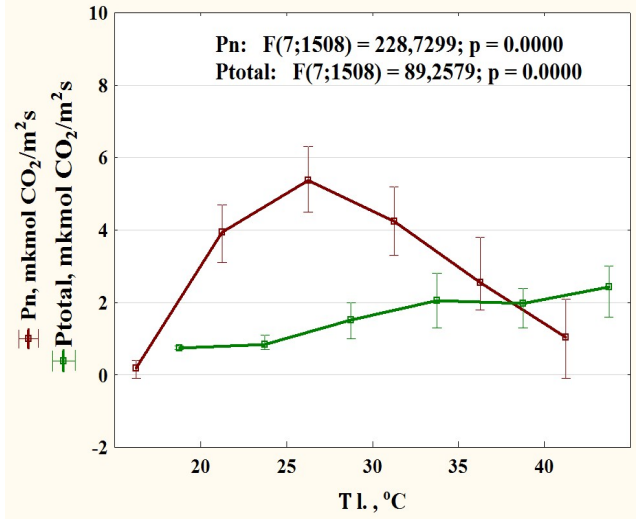

$\mathrm{C}$

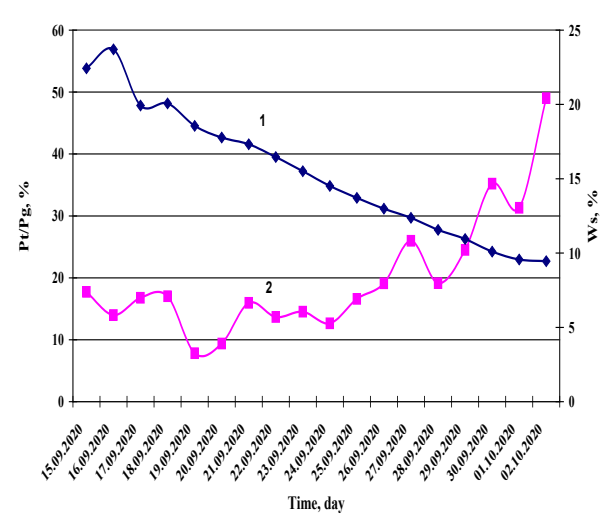

$\mathrm{D}$

Fig. 2. Dependence of various processes of Quércus pubéscens Willd: A - net photosynthesis rate $\left(\mathrm{P}_{\mathrm{n}}\right)$, total leaf respiration $\left(\mathrm{R}_{\mathrm{t}}\right)$ on soil moisture $\left(\mathrm{W}_{\mathrm{s}}\right)$; B - between total respiration rate $\left(\mathrm{R}_{\mathrm{t}}\right)$, dark respiration rate $\left(R_{d}\right)$, and photorespiration rate $\left(R_{p h}\right) ; C$ - between net photosynthesis rate $\left(P_{n}\right)$, total respiration rate $\left(R_{t}\right)$, and leaf temperature $\left(T_{1}\right)$; D - between $R_{t} / P_{g}$ ratio and soil moisture $\left(W_{s}\right)$ [Compiled by the authors]

\section{Discussion}

There are known works on determining favorable and limiting environmental factors for growing Quercus pubescens Willd. [5,6,7,10]. For the first time, we obtained quantitative values of optimal and threshold values of environmental factors that limit the rate of net photosynthesis and the intensity of transpiration during the summer active growth phase for the Southern coast of the Crimea.

The reaction of physiological and biochemical reactions of Quercus pubescens Willd. the effect of high air temperature was studied in the sub-Mediterranean region [8]. We have determined the temperature maximum of net photosynthesis for the Southern coast of Crimea (leaf temperature $\mathrm{Tl}=37^{\circ} \mathrm{C}$ ) and it can be considered as a thermal compensation point.

To determine the characteristics of the water regime of the studied species, we used the speed of the xylem flow in the plant shoot and the diameter of this shoot. During the dewatering process, these parameters decrease synchronously, which serves as a signal for watering the plant and can be used to optimize irrigation management.

To determine the proportion of respiration costs from true photosynthesis, we used the ratio $(\mathrm{Pt} / \mathrm{Pg})$. It was found that in the absence of soil drought, the share of respiratory costs from true photosynthesis is $22-24 \%$, and with soil moisture of $8-10 \%$, it increases to 55 $58 \%$.

A model of spatial analysis was developed to determine the territories favorable for the growth of pubescent oak [5]. The research results obtained by us make it possible to introduce it to other regions.

\section{Conclusion}

The genotypic features of Quércus pubéscens Willd. are revealed and the optimal and limiting conditions of its cultivation are found in accordance with the environmental conditions. 
The quantitative values of optimal and threshold values of environmental factors that limit the rate of net photosynthesis and the intensity of transpiration during the summer active growth phase and their relationship with stomatal conductivity and leaf temperature are obtained.

The speed of the xylem flow in the plant shoot and the diameter of this shoot decrease synchronously during the dewatering process, which serves as a signal for watering the plant and can be used to optimize irrigation management.

The optimal and limiting conditions of photosynthesis and respiration under the influence of soil drought are determined. The optimal values are: $\mathrm{W}_{\mathrm{s}}=26-28 \%, \mathrm{P}_{\mathrm{n}}=16$ $18 \mu \mathrm{mol} / \mathrm{m}^{2} \mathrm{c}$. With such soil moisture, the total respiration is $\mathrm{R}_{\mathrm{t}}=1.2-1.3 \mu \mathrm{mol} / \mathrm{m}^{2} \mathrm{c}$.

The temperature maximum of net photosynthesis is determined - in this case, net photosynthesis $\left(\mathrm{P}_{\mathrm{n}}\right)$ and total respiration $\left(\mathrm{R}_{t}\right)$ intersect at the point where the values of $\mathrm{P}_{n}$ and $\mathrm{R}_{\mathrm{t}}$ are equal to $2.2 \mu \mathrm{mol} / \mathrm{m}^{2} \mathrm{c}$. The leaf temperature is $\mathrm{T}_{1}=37^{\circ} \mathrm{C}$ and it can be considered as a thermal compensation point.

The integral indicator of the energy balance of the whole plant is the proportion of respiratory costs from true photosynthesis $\left(\mathrm{R}_{\mathrm{t}} / \mathrm{P}_{\mathrm{g}}\right)$. It was found that in the absence of soil drought, the share of respiratory costs from true photosynthesis is $20-23 \%$, and with soil moisture of $8-10 \%$, it increases to $55-58 \%$.

The obtained research results made it possible to introduce this species to other regions.

\section{References}

1. A. A. Annenkov, V. F. Ivanov, A. V. Khokhrin, Yu. A. Akimov, Methodological recommendations on prospecting for the design of the planting sites in the Crimea (Yalta, 1984)

2. V. P. Isikov, Yu. V. Plugatar, Wild-growing trees and bushes of the Crimea (Simferopol: ARIAL, 2018)

3. L. Dinca, E. Vechiu, M. Drăcea, Romania Sustainable Development Research, 2(1) (2020) https://doi.org/10.30560/sdr.v2n2p1

4. C. Cocozza, E. Paoletti, T. Mrak, S. Zavadlav, T. Levanič, H. Kraigher, A. Giovannelli, Y. Hoshika, Forests 11(8), 864 (2020) https://doi.org/10.3390/f11080864

5. V. Șimonca, S. RoȘca, A. ColiȘar, F. Rebrean, Ș. BilaȘco, Notulae Botanicae Horti Agrobotanici Cluj-Napoca 47(4), 1299-307 (2020) DOI: https://doi.org/10.15835/nb ha47411624

6. D. Sperlich, C. T. Chang, J. Peñuelas, C. Gracia, S. Sabaté, Tree Physiology 35, 50120 (2015) doi: 10.1093/treephys/tpv017.

7. P. Lionello, Glob Planet Change 63, 90-104 (2008) doi:10.1016/j.gloplacha .2007.09.005

8. N. Contran, M. S. Gunthardt-Goerg, T. M. Kuster, R. Cerana, P. Crosti, E. Paoletti Plant Biology, 157-168 (2012) DOI: 10.1111/j.1438 - 8677.2012.00627.x

9. J. D. Johnson, M. Michelozzi, R. Tognetti, Carbon physiology of Quercus pubescens Willd., growing at the Bossoleto $\mathrm{CO}_{2}$ spring in central Italy, 148 - 164 (Cambridge University Press, 2010) DOI: ttps://doi.org/10.1017/CBO9780511565236.013

10. M. Abubakr, S. Juma, R. Kalliopi, N. Basilios, S. Pavlos, Sudan J. Des. Res. 1(1) 7187 (2009)

11. P. Haldimann, A. Gallé, U. Feller, Canada Tree Physiology 28, 785-95 (2008) 
12. O. A. Ilnitsky, Yu. V. Plugatar, S. P. Korsakova, Methodology, instrument base and practice of phytomonitoring (Simferopol: ARIAL, 2018)

13. Physiological Plant Ecology: Ecophysiology and Stress Physiology of Functional Groups (Heidelberg: Springer-Verlag, 2003)

14. S. N. Drozdov, E. S. Kholoptseva, Scientific Notes of the Petrozavodst State University 2(131) 11-15 (2013)

15. H. Medrano, J. M. Escalona, J. Bota, J. Gulias, J. Flexas, Annals of Botany 89(7), 895905 (2002)

16. V Hurry, A U Igamberdiev, O Keerberg, T Parnik, O Atkin, J Zaragoza-Castells, P Gardestrom, Respiration in Photosynthetic Cells: Gas Exchange Components, Interactions with Photorespiration and the Operation of Mitochondria in the Light Plant Respiration: From Cell to Ecosystem, ed H. Lambers and M. Ribas-Carbo 43-61 (Berlin: Springer-Verlag, 2005)

17. S. N. Drozdov, V. K. Kurets, Some aspects of ecological physiology of plants, 172 (Petrozavodsk: Petrozavodsk State University, 2003)

18. Z. F. Rahmankulova, Bulletin of the Bashkir University 35(2-1) 1141-54 (2009) 